Butler and Ethics 


\title{
Critical Connections
}

A series of edited collections forging new connections between contemporary critical theorists and a wide range of research areas, such as critical and cultural theory, gender studies, film, literature, music, philosophy and politics.

\author{
Series Editors \\ Ian Buchanan, University of Wollongong \\ James Williams, University of Dundee \\ Editorial Advisory Board \\ Nick Hewlett \\ Gregg Lambert \\ Todd May \\ John Mullarkey \\ Paul Patton \\ Marc Rölli \\ Alison Ross \\ Kathrin Thiele \\ Frédéric Worms
}

Titles available in the series

Badiou and Philosophy, edited by Sean Bowden and Simon Duffy Agamben and Colonialism, edited by Marcelo Svirsky and Simone Bignall

Laruelle and Non-Philosophy, edited by John Mullarkey and Anthony Paul Smith

Virilio and Visual Culture, edited by John Armitage and Ryan Bishop Rancière and Film, edited by Paul Bowman

Stiegler and Technics, edited by Christina Howells and Gerald Moore Badiou and the Political Condition, edited by Marios Constantinou Nancy and the Political, edited by Sanja Dejanovic

Butler and Ethics, edited by Moya Lloyd

Latour and the Passage of Law, edited by Kyle McGee

Forthcoming titles

Agamben and Radical Politics, edited by Daniel McLoughlin

Rancière and Literature, edited by Julian Murphet and Grace Hellyer

Nancy and Visual Culture, edited by Carrie Giunta and Adrienne Janus

Balibar and the Citizen/Subject, edited by Warren Montag and Hanan Elsayed

Visit the Critical Connections website at www.euppublishing.com/ series/crcs 


\section{Butler and Ethics}

Edited by Moya Lloyd

\section{EDINBURGH}

University Press 
(C) editorial matter and organisation Moya Lloyd, 201 5

(C) the chapters their several authors, 2015

Edinburgh University Press Ltd

The Tun - Holyrood Road

I 2 (2f) Jackson's Entry

Edinburgh EH8 8PJ

www.euppublishing.com

Typeset in II/I 3 Adobe Sabon by Servis Filmsetting Ltd, Stockport, Cheshire, and printed and bound in Great Britain by CPI Group (UK) Ltd, Croydon CRo 4 YY

A CIP record for this book is available from the British Library

ISBN $978 \circ 748678846$ (hardback)

ISBN $978 \circ 74867886$ ○ (webready PDF)

ISBN $978 \circ 748678877$ (epub)

The right of Moya Lloyd to be identified as Editor of this work has been asserted in accordance with the Copyright, Designs and Patents Act I988, and the Copyright and Related Rights Regulations 2003 (SI No. 2498). 